\title{
Review Paper
}

\section{Profitability and Resource Use Efficiency of Rice-based Cropping Systems-Evidences from Kerala}

\author{
Divya Lekshmi, U*, M.N. Venkataramana and G.M. Gaddi \\ Department of Agricultural Economics, University of Agricultural Sciences, Bangalore, India \\ "Corresponding author: divyalk89@gmail.com (ORCID ID: 0000-0002-0530-835X)
}

Received: $10-09-2021$

Revised: $13-11-2021$

Accepted: $12-12-2021$

\begin{abstract}
Rice-based cropping systems refer to the type and sequence of crops grown along with rice on a piece of land in a year. Kuttanad rice ecosystems in Kerala follow different rice-based cropping systems to make cultivation lucrative. The profitability and resource use efficiency of the identified rice-based cropping systems in Kuttanad was estimated using the costs and returns method and efficiency ratio calculation. A random sample of 160 paddy farmers from Alappuzha and Kottayam districts were surveyed for data collection. The study identified three rice-based cropping systems, CS-I (rice mono-crop), CS-II (rice-rice) and CS-III (rice-fish) sequential cropping system in the study districts. The cost of cultivation for CS-I, CS-II and CS-III was ₹ 88,999, ₹ 1,77,684 and ₹ $1,75,268$, respectively. Human labour was the significant cost component under all three systems. The study outcomes revealed that CS-III (rice-fish) was the most lucrative rice-based system among the three rice-based systems with a return per rupee expenditure ratio of 2.52, followed by CS-I (1.88) and CS-II (1.60). Productivity of the resources utilized was assessed by fitting the Cobb-Douglas production function. The efficiency of the inputs utilized was far from unity indicated the inefficient use of resources in the three cropping systems. Machine labour, human labour and lime were underused under CS-I, while the plant protection chemicals applied to check the pest and disease attack were over utilized under the same system. Under CS-II, resources such as machine labour and fertilizer were underutilized, whereas human labour was over-utilized for autumn rice. The resources such as human labour and plant protection chemicals were underutilized for rice production under CS-III, with MVP to MFC ratios of 3.72 and 9.1, respectively. At the same time, the feed used for fish production was underutilized with a very high-efficiency ratio indicating the scope of increasing fish feed to enhance the fish yield. The government of Kerala should reinstate the 'One rice and one fish' scheme which would earn considerate returns to the paddy farmers in Kerala. Government initiatives to establish public custom hiring centers would reduce the cost incurred for machine labour.
\end{abstract}

\section{HIGHLIGHTS}

(0 The rice-fish sequential cropping system was highly profitable than the CS-I and CS-II in the Kuttanad rice farming system.

(0 The MVP/MFC ratios highlighted the inefficiency in resource use and the scope of reallocation of resources.

Keywords: Cobb-Douglas production function, resource use efficiency ratio and cost estimation

Rice is the staple food of Keralites and Kuttanad wetland system of paddy cultivation is one of the different agro-ecosystems in Kerala. Paddy cultivation in Kuttanad is considered to be a unique farming practice as this is the only below-sea level farming in India. Kuttanad is known as the rice bowl of Kerala along with Palakkad district
(Mamata et al. 2019). Despite the favourable soil and climate for paddy cultivation, the area under paddy

How to cite this article: Divya Lekshmi, U., Venkataramana, M.N. and Gaddi, G.M. (2021). Profitability and Resource Use Efficiency of Ricebased Cropping Systems-Evidences from Kerala. Economic Affairs, 66(04): 643-649.

Source of Support: None; Conflict of Interest: None

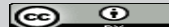


fields has been declining for years (Divya Lekshmi and Venkataramana, 2020). According to Suchitra (2015), the inability of paddy cultivation to compete with the rewarding prices of cash crops such as rubber and coconut has led to a decline in paddy cultivation in the State. Besides, labour scarcity, exorbitant wage rates, the construction boom and the thriving real estate business are reasons for the decline in interest in paddy cultivation in Kerala.

Along with this, the inefficiency in the use of resources results in unsustainable agricultural practices. This inefficiency in resource allocation can be linked to various reasons, for instance, market distortions due to the government interventions in the form of subsidies and various other means, price volatility, product demand etc. (Rohith et al. 2018). After the implementation of the Kerala Conservation of Paddy land and wetland Act in 2008 to check the indiscriminate conversion of paddy land and wetland, the government of Kerala came up with several paddy promotional activities in the form of input assistance, production bonuses, pumping subsidies etc to ensure the profitability of rice and rice-based cropping systems in the State. These government aids might have acted as market distortions thereby affecting the resource use efficiency and profitability of rice-based cropping systems. In the present study, an attempt has been made to assess the efficiency in resource use and the economic viability of the paddy farmers in the study region.

\section{METHODOLOGY}

\section{Study area and sampling}

The study focussed mainly on the Kuttanad wetland paddy cultivation that spreads over the Alappuzha, Kottayam and Pathanamthitta districts (Sabu et al. 2020). Alappuzha and Kottayam districts were selected for the study. Four blocks (Champakulam, Haripad, Eattumanoor and Kaduthuruthy) two each from these two districts were chosen for data collection. Random samples comprised of 160 paddy farmers were interviewed for the collection of fieldlevel information.

\section{Analytical tools}

\section{Costs and returns estimation}

The cost of cultivation of the crops grown in the area of study were calculated based on the variable and fixed costs concept.

$$
C O C=T V C+T F C
$$

Where, $C O C=$ Cost of Cultivation

$$
\text { TVC }=\text { Total Variable Cost }
$$

TFC $=$ Total Fixed Cost

Total Variable cost: It constitutes several components that are detailed below:

1. Labour cost: Includes, human labour both hired and family labour. The imputed value at market prices was considered for family labour. Female workdays were converted to man days by multiplying it by 0.66 .

2. Machine labour cost: This is the rent paid out for tractors, tillers and combine-harvesters that are used for land preparation and paddy harvest.

3. Input cost: This cost was based on the purchase of inputs involved in the production, namely paddy seed, fish fingerling (fish seed), farmyard manure, chemical fertilizers, plant protection chemicals, lime, etc.

4. Irrigation cost: Water needs to be pumped out of the fields of Kuttanad as it lies below sea level. The expenses incurred for pumping out water from the paddy field were taken under the irrigation cost.

5. Nursery cost: The cost incurred in the cleaning and maintenance of the fish nursery is referred to as the nursery cleaning cost.

6. Interest on working capital: Interest on working capital was calculated at bank rate @ $7.25 \%$ of interest which was prevailing in the year 2017-18.

Total Fixed Costs: Obtained by summing up the components given below:

1. Depreciation: Straight-line method was used for the calculation of depreciation.

2. The rental value of land: The prevailing rent given for the leased land was considered the rental value for the land.

3. Land revenue: Calculated based on the payments made by the farmers in the revenue department as tax. 


\section{Returns/Income}

(a) Gross returns: Gross returns were obtained by multiplying the total produce with its unit price.

(b) Net Returns: Calculated by deducting total cost of cultivation from the gross returns.

\section{Resource use efficiency of rice production under CS-I, CS-II and CS-III}

CS-I or Cropping System-I (Rice mono-crop): A single rice crop was cultivated in the field, leaving the land fallow for the rest of the year.

CS-II or Cropping System-II (Rice -Rice): Two rice crops were cultivated in a year.

CS-III or Cropping System-III (Rice-Fish) sequential cropping system: Fish was cultivated in rice fields after a single rice crop in a year cycle.

Rice is cultivated in all three rice-based systems. Hence, the resource use efficiency for rice cultivation under CS-I, CS-II and CS-III was assessed by fitting the Cobb-Douglas production function using the parameters as given below. The parameters used were same for all rice production systems.

The specification of the equation was as follows,

$$
Y=a X_{1}^{b 1} X_{2}^{b 2} X_{3}^{b 3} X_{4}^{b 4} X_{5}^{b 5} X_{6}^{b 6} e^{u}
$$

Where,

$Y=$ Value of output per farm (₹)

$X_{1}=$ Cost of human labour (₹)

$X_{2}=$ Cost of machine labour (₹)

$X_{3}=$ Cost of fertilizer (₹)

$X_{4}=$ Cost of seed (₹)

$X_{5}=$ Cost of lime (₹)

$X_{6}=$ Cost of Plant Protection Chemicals (₹)

$a=$ Constant

$u=$ Random variable

$b_{1}$ to $b_{6}=$ elasticity coefficients of respective inputs.

Equation (1) was converted into the logarithmic form to facilitate the application of OLS (Ordinary Least Squares).

$$
\begin{gathered}
\ln Y=\ln a+b_{1} \ln X_{1}+b_{2} \ln X_{2}+b_{3} \ln X_{3}+ \\
b_{4} \ln X_{4}+b_{5} \ln X_{5}+b_{6} \ln X_{6}+u \ln e^{3}
\end{gathered}
$$

Resource use efficiency of fish production under CS-III (rice-fish)

The specification of the equation was as follows:

$$
Y=a X_{1}^{b 1} X_{2}^{b 2} X_{3}^{b 3} X_{4}^{b 4} e^{u}
$$

Where,

$Y=$ Value of fish yield per farm (₹)

$X_{1}=$ Cost of human labour (₹)

$X_{2}=$ Cost of fish fingerlings (₹)

$X_{3}=$ Cost of fish feed (₹)

$X_{4}=$ Cost of lime + manure slurry $(₹)$

$a=$ Constant

$u=$ Random variable

$b_{1}$ to $b_{4}=$ elasticity coefficients of respective inputs.

Equation (3) was converted into the logarithmic form to make it in a linear form:

$$
\begin{aligned}
& \ln Y=\ln a+b_{1} \ln X_{1}+b_{2} \ln X_{2}+b_{3} \ln X_{3}+ \\
& b_{4} \ln X_{4}+u \ln e
\end{aligned}
$$

\section{Efficiency ratio}

The marginal value product (MVP) ratio to the marginal factor cost (MFC) was used to find the resource use efficiency. MVP and MFC were computed from the estimated coefficients.

\section{Resource use efficiency ratio}

$$
r=\frac{R V P}{M F C}
$$

Where,

$r=$ Efficiency ratio

$M V P=$ Marginal value product of variable input $(₹)$ $M F C=$ Marginal factor cost (price per unit input) $(₹)$

\section{Marginal Value Product (MVP)}

Marginal Value Product (MVP) of $X_{\mathrm{i}^{\prime}}$ the $i^{\text {th }}$ input is estimated by the following formula:

$$
M V P=b i * \frac{G M(Y)}{G M\left(X_{i}\right)}
$$

$G M(Y)$ and $G M\left(X_{i}\right)$ represent the geometric means 
of output and input, respectively and $b_{i}$ is the regression coefficient of $i^{\text {th }}$ input.

If $r$ is $<1$, then resource is over-utilized,

If $r>1$, the resource is under-used

If $r=1$, it shows the resource is economically or optimally used.

\section{RESULTS AND DISCUSSION}

\section{Cropping systems identified}

There are three rice-based cropping systems identified in the study area: Cropping System-I (CSI) with a single rice crop and leaving the rest of the year fallow. A majority (65\%) of the sample farmers followed this system. Around 18 per cent of farmers followed CS-II or the rice-rice system where two rice crops, summer rice from December- January to March- April and autumn rice from May-June to September-October, were cultivated. Along with this, CS-III, the third cropping system where fish was cultivated in the main field after the autumn rice (Table 1).

\section{Estimation of costs and returns of rice and production under CS-I, CS-II and CS-III}

The cost of cultivation and returns of rice cultivation under CS-I, CS-II and CS-III in the study area were given in table 2 . The variable cost component formed the major part of the cost of cultivation, with around 80 percent of the total cost of cultivation for CS-I and CS-II, whereas, for CS-III, rice production, the variable cost was 70 percent of the total cost. Among the various variable cost components, hired labour accounted for a significant share in all three systems. Cost incurred for human labour constituted lion share of the total cost of cultivation, which formed around 32-39 percent of the cost of cultivation. Autumn rice cultivated under CS-II accounted for the significant share of human labour cost, i.e., around 39 per cent. One of the reasons for the larger share is the exorbitant wage rate ( $₹ 750$ per day) prevailing in the study area. Apart from that, machine labour (16-17 \%), plant protection chemicals (8-9 \%) and seed (6-7\%) also contributed remarkably towards the cost of cultivation of rice under CS-I and CS-II.

In contrast, the plant protection chemical use was at the lower side for rice production under
CS-III, where fish is cultivated along with rice. In machine labour, the rent paid out for the tractors, tillers and the combine-harvesters ( $₹ 1000$ to $₹$ 1800) hired from private agencies resulted in a significant increase in the share of machine labour cost. The current findings are in accordance with the findings of Thomas (2002) that the machine labour cost formed around 10-12 percent of the cost of paddy cultivation. The average yield of rice from CS-I and summer rice was around 58 quintals per hectare. While the paddy yield from autumn rice was around 47 quintals in CS-II and 37 quintals in CS-III. This low rice productivity under CS-III was due to the low application of plant protection chemicals and chemical fertilizers. The net returns were highest from the summer rice under the CS-II system. The cost of cultivation of fish under CS-III was ₹ $1,16,464$. As fish cultivation requires strong external bunds, proper netting facilities and laborious harvesting, the labour requirement for fish production was very high. Hence, the human labour cost accounted for around 36.87 percent of the total cost of fish cultivation in the overall study area. The other major variable cost components were fish fingerlings cost and seed cost, which formed around 20 percent and 17 percent of the total cost of cultivation.

Table 1: Cropping systems identified in the study area

\begin{tabular}{lllll}
\hline $\begin{array}{l}\text { S1. } \\
\text { No }\end{array}$ & $\begin{array}{l}\text { Cropping } \\
\text { systems }\end{array}$ & $\begin{array}{l}\text { Alappuzha } \\
(\mathbf{n}=\mathbf{8 0})\end{array}$ & $\begin{array}{l}\text { Kottayam } \\
(\mathbf{n}=\mathbf{8 0})\end{array}$ & $\begin{array}{l}\text { The overall } \\
\text { study area } \\
(\mathbf{n}=160)\end{array}$ \\
\hline 1 & $\begin{array}{l}\text { CS-I (rice } \\
\text { mono-crop) }\end{array}$ & $53(66.25)$ & $51(63.75)$ & $104(65.00)$ \\
2 & $\begin{array}{l}\text { CS-II (rice }- \\
\text { rice) } \\
\text { CS-III (rice- } \\
\text { fish) }\end{array}$ & $12(18.75)$ & $14(17.5)$ & $29(18.13)$ \\
\end{tabular}

Note: 1. Figures in parentheses indicate the percentage of the total sample. 2. CS-Cropping System

\section{The profitability of rice-based cropping systems}

The profitability comparison of the entire cropping system was given in table 3 . From table 3 , it was evident that out of the three rice-based cropping systems, CS-III with rice-fish integration was found more profitable with a return per rupee of 2.52, followed by CS-I, rice mono-cropping with 1.76 
Table 2: Costs and returns of the three rice-based cropping systems

\begin{tabular}{|c|c|c|c|c|c|c|c|c|c|c|c|}
\hline \multirow{3}{*}{$\begin{array}{l}\text { Sl. } \\
\text { No. }\end{array}$} & \multirow{3}{*}{ Particulars } & \multicolumn{3}{|c|}{$\begin{array}{l}\text { CS-I (rice } \\
\text { mono-crop) }\end{array}$} & \multicolumn{4}{|c|}{ CS-II (rice-rice) } & \multicolumn{3}{|c|}{ CS-III (rice-fish) } \\
\hline & & \multirow[b]{2}{*}{ Cost (₹) } & \multicolumn{2}{|c|}{ Summer rice } & \multicolumn{2}{|c|}{ Autumn rice } & \multicolumn{2}{|c|}{ Autumn rice } & \multicolumn{3}{|l|}{ Fish } \\
\hline & & & $\%$ & Cost (₹) & $\%$ & Cost (₹) & $\%$ & Cost (₹) & $\%$ & Cost (₹) & $\%$ \\
\hline \multirow[t]{12}{*}{ I } & Variable cost & & & & & & & & & & \\
\hline & Hired labour (mandays) & 30,981 & 34.81 & 26,695 & 31.86 & 32,530 & 34.64 & 16,302 & 27.72 & 40,563 & 33.02 \\
\hline & Family labour (mandays) & 2,026 & 2.28 & 3,800 & 4.54 & 3,992 & 4.25 & 2,047 & 3.48 & 2,374 & 1.93 \\
\hline & Machine labour (hours) & 15,071 & 16.93 & 14,114 & 16.84 & 16,099 & 17.15 & 9,346 & 15.89 & - & - \\
\hline & $\begin{array}{l}\text { Seed }(\mathrm{kg}) \text { or Fish fingerlings } \\
\text { (Nos) }\end{array}$ & 5,381 & 6.05 & 5,539 & 6.61 & 5,933 & 6.32 & 5,302 & 9.02 & 25,245 & 20.55 \\
\hline & Fertilizer $(\mathrm{kg})$ or fish feed $(\mathrm{kg})$ & 4,769 & 5.36 & 3,205 & 3.83 & 3,895 & 4.15 & 2,577 & 4.38 & 19,849 & 16.16 \\
\hline & Lime (kg) (lime + FYM for fish) & 2,498 & 2.81 & 2,179 & 2.60 & 2,286 & 2.43 & 1,508 & 2.56 & 6,344 & 5.16 \\
\hline & Plant protection chemical (l) & 7,206 & 8.10 & 8,047 & 9.60 & 8,398 & 8.94 & 1,409 & 2.40 & - & - \\
\hline & Water pumping charges (₹) & 1,453 & 1.63 & 1,170 & 1.40 & 1,494 & 1.59 & 1,453 & 2.47 & - & - \\
\hline & Nursery cleaning & - & - & - & - & - & - & - & - & 1,307 & 1.06 \\
\hline & $\begin{array}{l}\text { Interest on working capital @ } \\
7.25 \%\end{array}$ & 1,619 & 1.82 & 1,511 & 1.80 & 1,741 & 1.85 & 1,331 & 2.26 & 3,349 & 2.82 \\
\hline & Total variable cost (₹) & 71,004 & 79.78 & 66,260 & 79.08 & 76,368 & 81.33 & 41,275 & 70.19 & 99,031 & 80.70 \\
\hline \multirow[t]{6}{*}{ II } & Fixed cost & & & & & & & & & & \\
\hline & Depreciation & 792 & 0.89 & 396 & 0.47 & 396 & 0.42 & 396 & 0.67 & 305 & 0.26 \\
\hline & Land revenue & 96 & 0.11 & 48 & 0.06 & 48 & 0.05 & 48 & 0.08 & 48 & 0.04 \\
\hline & The rental value of land & 16,250 & 18.26 & 16,250 & 19.39 & 16,250 & 17.31 & 16,250 & 27.63 & 16,250 & 13.95 \\
\hline & Interest on fixed capital @ $10 \%$ & 857 & 0.96 & 835 & 1.00 & 835 & 0.89 & 835 & 1.42 & 830 & 0.71 \\
\hline & Total fixed cost & 17,994 & 20.22 & 17,529 & 20.92 & 17,528 & 18.67 & 17,528 & 29.81 & 17,433 & 14.97 \\
\hline III & The total cost of cultivation & 88,999 & 100.00 & 83,788 & 100.00 & 93,896 & 100.00 & 58,804 & 100.00 & $1,16,464$ & 100.00 \\
\hline \multirow[t]{5}{*}{ IV } & Returns & & & & & & & & & & \\
\hline & Main product $(\mathrm{q})$ & 58.20 & & 58.32 & & 47 & & 37.7 & & 27.24 & \\
\hline & Gross returns (₹) & $1,56,849$ & & $1,57,172$ & & $1,26,665$ & & 101601.5 & & $3,40,438$ & \\
\hline & Net returns (₹) & 67,850 & & 73,384 & & 32,769 & & 42,798 & & $2,23,974$ & \\
\hline & $\begin{array}{l}\text { Returns per rupee of } \\
\text { expenditure }\end{array}$ & 1.76 & & 1.88 & & 1.35 & & 1.73 & & 2.92 & \\
\hline V & Cost of production $(₹ / q)$ & 1,529 & & 1,437 & & 1,997 & & 1,560 & & 4,275 & \\
\hline
\end{tabular}

Note: Unit price of one quintal rice is ₹ 2,695 and one quintal fish is ₹ 12,500.

Table 3: Profitability of rice-based cropping systems (₹/ha)

\begin{tabular}{lllllll}
\hline \multirow{2}{*}{ S1. No. } & \multirow{2}{*}{ Cropping system } & \multicolumn{2}{l}{$\begin{array}{l}\text { System Cost of System Gross } \\
\text { cultivation }\end{array}$} & $\begin{array}{l}\text { Net } \\
\text { Returns }\end{array}$ & $\begin{array}{l}\text { Returns per rupee } \\
\text { Returns }\end{array}$ & $\begin{array}{l}\text { Cost of production } \\
\text { (₹/q) }\end{array}$ \\
\hline 1 & CS-I (rice mono-crop) & 88,999 & $1,56,849$ & 67,850 & 1.76 & 1,529 \\
2 & CS-II (rice-rice) & $1,77,684$ & $2,83,837$ & $1,06,153$ & 1.60 & 1,687 \\
3 & CS-III (rice-fish) & $1,75,268$ & $4,42,040$ & $2,66,772$ & 2.52 & - \\
\hline
\end{tabular}

return over every one-rupee expenditure and the least profitable system was the CS-II with 1.6 return per rupee of expenditure.

\section{Resource use efficiency of rice production under CS-I (rice mono-crop)}

Table 4 shows that the calculated $\mathrm{F}$ value is greater than the critical $F$ value hence, the estimated model is a good fit that significantly explains the variation in the total rice production. The coefficient for human labour cost (0.51), machine labour cost (0.35) and lime cost $(0.85)$ were found positive with an MVP to MFC ratio greater than one, which showed that these resources were under-utilized in the production of rice under CS-I. Comparable results were found in the study of Suresh and Reddy (2006) regarding the under-utilization of human labour. The coefficient obtained for plant protection chemicals was negative and significant, with an 
Table 4: Resource use efficiency of rice and fish production under CS-I, CS-II and CS-III

\begin{tabular}{|c|c|c|c|c|c|c|c|c|c|c|c|}
\hline \multirow{3}{*}{$\begin{array}{l}\text { Sl. } \\
\text { No. }\end{array}$} & & \multirow{2}{*}{\multicolumn{2}{|c|}{$\begin{array}{l}\text { CS-I } \\
\text { Rice } \\
\text { mono-crop }\end{array}$}} & \multirow{2}{*}{\multicolumn{2}{|c|}{$\begin{array}{l}\text { CS-II } \\
\begin{array}{l}\text { Summer } \\
\text { rice }\end{array}\end{array}$}} & \multicolumn{5}{|c|}{ CS-III } & \multirow[b]{3}{*}{$\begin{array}{l}\text { MVP } \\
\text { MFC }\end{array}$} \\
\hline & \multirow{2}{*}{ Variables } & & & & & $\begin{array}{l}\text { Autumn } \\
\text { rice }\end{array}$ & & $\begin{array}{l}\text { Autumn } \\
\text { rice }\end{array}$ & & Fish & \\
\hline & & Coefficient & $\begin{array}{l}\text { MVP/ } \\
\text { MFC }\end{array}$ & Coefficient & $\begin{array}{l}\text { MVP/ } \\
\text { MFC }\end{array}$ & Coefficient & $\begin{array}{l}\text { MVP/ } \\
\text { MFC }\end{array}$ & Coefficient & $\begin{array}{l}\text { MVP/ } \\
\text { MFC }\end{array}$ & Coefficient & \\
\hline 1 & $\begin{array}{l}\text { Cost human labour } \\
\text { (₹) }\end{array}$ & $0.51^{* * *}$ & 2.49 & 0.09 & 0.58 & $-0.42^{*}$ & -1.49 & $0.69^{* * *}$ & 3.72 & 0.63 & 5.36 \\
\hline 2 & $\begin{array}{l}\text { Cost of machine } \\
\text { labour }(₹)\end{array}$ & $0.35^{* *}$ & 3.65 & $0.33^{* * *}$ & 3.9 & 0.02 & 0.18 & 0.24 & 2.44 & - & - \\
\hline 3 & Cost of fertilizer (₹) & -0.02 & -0.45 & $0.57^{* * *}$ & 10.9 & $1.15^{* * *}$ & 16.21 & -0.19 & -8.89 & - & - \\
\hline 4 & Cost of seed $(₹)$ & 0.01 & 0.18 & -0.04 & -1.45 & 0.1 & 2.06 & -0.01 & -0.16 & - & - \\
\hline 5 & Cost of lime (₹) & $0.85^{* * *}$ & 52.89 & 0.03 & 2.02 & 0.59 & 32.36 & 0.11 & 6.62 & - & - \\
\hline 6 & Cost of PPC (₹) & $-0.71^{* * *}$ & -17.21 & 0.005 & 0.12 & -0.43 & -6.53 & $0.16^{* *}$ & 9.1 & - & - \\
\hline 7 & Cost of fish feed (₹) & - & - & - & - & - & - & - & - & $0.91^{* * *}$ & 16.03 \\
\hline 8 & $\begin{array}{l}\text { Cost of fish } \\
\text { fingerlings (₹) }\end{array}$ & - & - & - & - & - & - & - & - & -0.27 & -4 \\
\hline 9 & $\begin{array}{l}\text { Cost of lime-manure } \\
\text { slurry (₹) }\end{array}$ & - & - & - & - & - & - & - & - & -0.29 & -16.75 \\
\hline & R-value & & 0.9 & & 0.8 & & 0.81 & & 0.89 & & 0.75 \\
\hline & F-value & & 182 & & 35 & & 20.57 & & 108.17 & & 14.75 \\
\hline
\end{tabular}

Note: *****, *significant at 1, 5 and 10 per cent probability levels, respectively, CS - Cropping System, PPC-Plant Protection Chemicals, MVP - Marginal Value Product, MFC - Marginal Factor Cost.

MVP to MFC ratio of less than one. Hence, the plant protection chemicals were over-utilized under CS-I.

\section{Resource use efficiency of summer and autumn rice production under CS-II (rice-rice)}

The results in table 4 show that machine labour and fertilizer was sub- optimally used for summer rice production under CS-II. While in autumn rice, the elasticity coefficient for fertilizer cost was 1.15 and for human labour was -0.42 . The MVP to MFC ratio indicated that the labour was over-utilized and the fertilizers were underutilized under autumn rice.

\section{Resource use efficiency of rice and fish production under CS-III (rice-fish)}

The ratio of the marginal value product to the marginal factor cost indicated the scope of increase of both human labour and plant protection chemicals usage in rice production under CS-III (Table 4). These results contradicted the results of Dominic (2019), where weedicide was over-utilized in rice production. Fish feed was observed to be underused for fish production with an MVP to MFC ratio of 16.03. The findings of Aswathy and Joseph (2019) on coastal cage fish farming match the current results.

\section{CONCLUSION}

The three rice-based cropping systems identified in the study area were profitable, with a decent return of around 1.6 to 2.52 rupees over a rupee of expenditure. Rice-fish sequential cropping is the best choice that the Kuttanad paddy farmers can adopt, bringing better profit than CS-I and CS-II. As the MVP to MFC ratio is far from unity in most of the resources analyzed, the resources were not optimal in all the three rice-based cropping systems. Training, demonstrations and field trials were required to strengthen the farmer's knowledge in utilizing the resources effectively. Human labour was found underutilized for rice production under CS-I and CS-III, whereas, it was over-utilized for autumn rice under CS-II. Enhancing the application of fish feed for fish production under CS-III would positively reflect in the fish yield. Efficient use of resources would assure the physical outcome as well as sustainable agriculture. Hence an efficient resource usage in the rice-fish cropping system is a promise to the paddy farmers. Government should come up with measures to promote ricefish sequential farming system in the state. Reestablishment of 'Oru Nellum Oru Meenum' ('One 
Rice One Fish') scheme would help to attract more farmers towards rice-fish integrated farming system. In order to curtail the increasing cost of cultivation of rice, government should take initiatives to establish public custom hiring centres nearer to paddy growing areas so as to reduce the machine labour cost.

\section{REFERENCES}

Sabu, A.S., Padma Rani and Vidyavathi, A. 2020. Economic analysis of integrated farming systems in the Kuttanad region of Kerala state: India. A case study. J. App. and Natural Sci., 12(2): 270-276.

Aswathy, N. and Imelda Joseph. 2019. Economic feasibility and resource use efficiency of coastal cage fish farming in Kerala. Eco. Affairs, 64(1): 151-155.

Divya Lekshmi, U. and Venkataramana, M.N. 2020.Growth and instability analysis of paddy area, production and productivity in Kerala, with special reference to the Kerala Conservation of Paddy land and wetland Act, 2008. Int. J. Agri. Env. and Biotech., 13(1): 93-98.
Dominic, T.K., Franklin, N.M. and Al Hassan, H. 2019. Technical and resource-use-efficiency among smallholder rice farmers in Northern Ghana. Cogent Food and Agri., 5: 1-15.

Mamatha. G. Nair., Jayalekshmi, G. and. Kishore Kumar, N. 2019. Utility of integrated farming systems: A perception study from Kuttanad. Agri. Sci. Digest, 39(4): 332-334.

Rohith, G.V., Jaganath Olekar, Rashmi, K.S. and Dhananjaya Swamy, P.S. 2018. Resource use efficiency of crops in north-eastern dry zone of Karnataka. Int. J. Agri. Env. Biotech., 11(2): 365-369.

Suchitra, M. 2014. Rice at risk. Down to Earth. https://www. downtoearth.org.in

Suresh, A. and Kesav Reddy, T.R. 2006. The resource use efficiency of paddy cultivation in Peechi command area of Thrissur district of Kerala. Agri. Eco. Res. Rev., 19(1-6): 159-171.

Thomas, P.M. 2002. The problems and prospects of paddy cultivation in Kuttanad region. A case study of Ramankari village in Kuttanad Taluk. Aproject of KRPLLD, Thiruvananthapuram. 
